
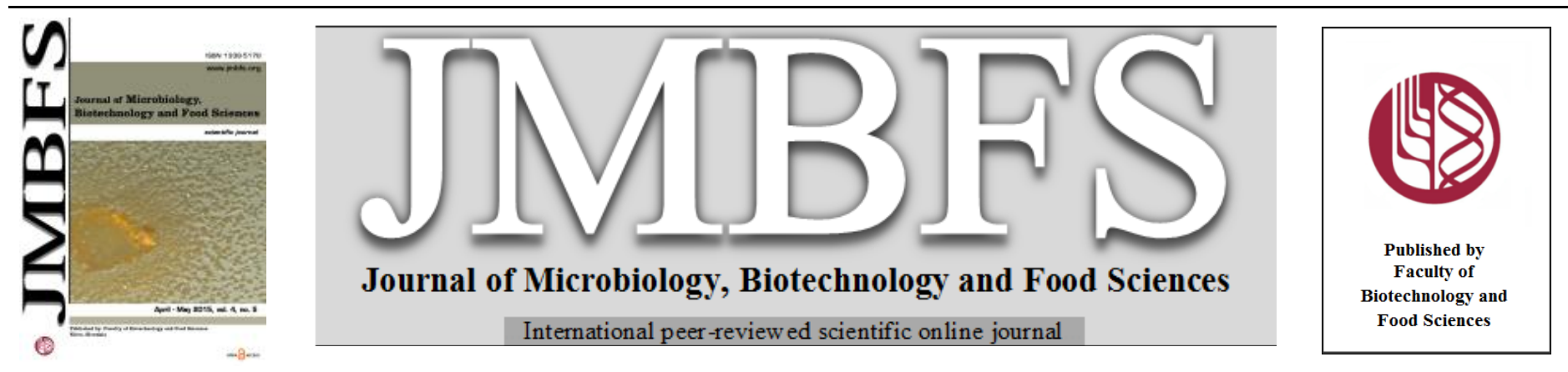

\title{
THE USE OF ENZYMES FOR ETHANOL, METHANOL AND FORMALDEHYDE DETERMINATION IN FOOD PRODUCTS
}

\author{
Władimir Sibirnyj ${ }^{*}{ }^{1}$ Dorota Grabek-Lejko ${ }^{1}$, Mykhailo Gonchar ${ }^{2,3}$
}

Address(es): Władimir Sibirnyj, PhD,

${ }^{1}$ University of Rzeszow, Faculty of Biology and Agriculture, Department of Biotechnology and Microbiology, Zelwerowicza 4, 35-601, Rzeszow, Poland, Phone number: 0048177855438.

${ }^{2}$ Institute of Cell Biology, NAS of Ukraine, 14/16 Drahomanov Str., 79005 Lviv, Ukraine.

${ }^{3}$ Institute of Applied Biotechnology and Basic Sciences, Rzeszów University, Sokolowska 26, PL-36-100 Kolbuszowa, Poland.

*Corresponding author: vsibirny@gmail.com

doi: 10.15414/jmbfs.2015.4.5.393-397

\section{ARTICLE INFO}

Received 6. 1. 2015

Revised 4. 2. 2015

Accepted 18. 2. 2015

Published 1. 4. 2015

Regular article

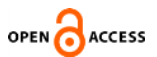

\section{ABSTRACT}

There is a need for the development and the use of analytical methods for assaying ethanol, methanol and formaldehyde in foods. Ethanol is a major component of a variety of alcoholic beverages and is an ingredient of a number of foodstuffs. Formaldehyde and methanol are produced on the large scale, are very toxic and have mutagenic and carcinogenic action on living organisms. The presence of toxic methanol and formaldehyde in foods can lead to severe poisoning and even death. Many current methods for the determination of ethanol, methanol and formaldehyde are based on the use of enzymes. The article presents an overview of the classical enzymatic and biosensors' methods for the analysis of these compounds.

Keywords: Ethanol, methanol, formaldehyde, enzymatic analysis, biosensor

\section{INTRODUCTION}

Environmental monitoring, as well as a quality control of food and drinking water is becoming increasingly important in programs to improve the living conditions and human nutrition. Although many physico-chemical methods of determination of methanol, ethanol and formaldehyde are available, there is a growing interest in bioanalytical approaches (Reshetilov et al., 2011; Trotsenko \& Torgonskaya, 2011). They exploit highly specific enzymes, as well as enzyme-based and microbial biosensors. For the implementation of biosensor's methods in wide practice, research is required on designing bio-elements with optimal parameters, including the creation of enzymatic and microbial sensor elements with the necessary bioanalytical characteristics.

\section{Ethanol, methanol and formaldehyde}

Ethanol (EtOH) is produced in large amounts; about $75 \%$ of it is used as a fuel for internal combustion engines and only $15 \%$ - for the preparation of alcoholic beverages and other aims. Global ethanol production will rise to over 90 billion liters in 2014 (www.globalrfa.com, 2014).

Methanol $(\mathrm{MeOH})$ plays an important role as a raw material in chemical synthesis. Most of the methanol is used in the production of formaldehyde. $\mathrm{MeOH}$ is also used in the plastics industry, for production of biofibers, as well as an additive to gasoline. $\mathrm{MeOH}$ occurs naturally in very low amounts in tissues of humans, animals and plants. It is a natural constituent of blood, urine and saliva and expired air and has also been found in mother's milk. Humans have a background body burden of $0.5 \mathrm{mg} / \mathrm{kg}$ body weight. Levels of methanol in expired air, of normal, healthy non-smoking subjects are reported to range from 0.06 to $0.49 \mu \mathrm{g} / \mathrm{L}$ (Krotoszynski et al., 1979). It is believed that dietary sources are only partial contributors to the total body pool of methanol (Stegink $\boldsymbol{e t}$ al., 1981). It has been suggested that methanol is formed by the activities of the intestinal microflora or by other enzymatic processes (Axelrod \& Daly, 1965) Methanol is also very toxic alcohol to mammals. Drinking methanol, mostly accidentally, causes severe metabolic acidosis leading to blindness, and neurological changes to the inevitable and death (Medinsky et al., 1997). Ora lethal dose of methanol for human ranges from $340 \mu \mathrm{g}$ to $1 \mathrm{mg} / \mathrm{kg}$ of body weight (Wang et al., 2004) Alcoholic beverages may contain the minimum allowable impurities of methanol, however, there are cases of poisoning including fatal when consuming beverages, acquired in the trade network. In 2012 in the Czech Republic reported 38 fatal poisoning with methanol. In Poland, with 21 confirmed methanol poisoning, 12 proved fatal. Methanol has become a serious problem when in 2010 the European Union has committed to add it to concentrate antifreeze windscreen fluid instead of ethanol (much cheaper).

Formaldehyde (FA) like methanol is an important analyte in monitoring of many industrial products, foodstuffs and pharmaceuticals (Gerberich \& Seaman, 1994). In 2013, the annual world production of formaldehyde was estimated to be more than 40 million metric tonnes (Magnusson, 2013). FA causes histopathological damages and DNA-protein cross-linking in the nasal mucosa of rats and rhesus monkeys (Casanova et al., 1989). FA is generated also in some advanced technologies of potable water pre-treatment including the ozonation process, as a result of the reaction of ozone with humus traces (Schechter $\boldsymbol{\&}$ Singer, 1995). In extreme cases, some frozen fish, especially of the Gadoid species, can accumulate up to $200 \mathrm{mg}$ of FA per $\mathrm{kg}$ of wet weight due to the enzymatic degradation of a natural fish component - trimethylamine oxide (Rehbein et al., 1995; Pavlishko et al., 2003).

Most of the known methods for determination of ethanol, methanol and formaldehyde are not very selective and sensitive enough or they are too expensive. Among enzymatic approaches, methods based on alcohol oxidase isolated from yeast overproducer - Hansenula (Ogataea) polymorha are most promising. Alcohol oxidase in vitro is capable of oxidizing methanol, as well as aliphatic alcohols, including ethanol. Another $H$. polymorpha enzyme of important bioanalytical value is formaldehyde dehydrogenase, which can be used in formaldehyde determination.

\section{Ethanol, methanol and formaldehyde analyzing with the use of enzymes}

One of the most used enzymatic method for the determination of ethanol is based on the oxidation of ethanol to acetaldehyde by alcohol dehydrogenase (ADH) (http://www.sigmaaldrich.com/content/dam/sigma-

aldrich/docs/Sigma/Bulletin/1/mak076bul.pdf; http://www.worthingtonbiochem.com/ADH/assay.html; Zanon et al., 2007). This reaction produces $\mathrm{NADH}$, which is determined photometrically. An alternative method of analysis is the use of alcohol oxidase (AOX) from methylotrophic yeast, which contains as a coenzyme tightly protein-bound FAD. AOX catalyzed reaction is irreversible and its ability to form hydrogen peroxide in the presence of alcohols, including ethanol, is used for quantitative determination of alcohols:

$\mathrm{CH}_{3} \mathrm{CH}_{2} \mathrm{OH}+\mathrm{O}_{2} \rightarrow \mathrm{CH}_{3} \mathrm{CH}=\mathrm{O}+\mathrm{H}_{2} \mathrm{O}_{2}$ 
Hydrogen peroxide, generated by AOX, is monitored in the coupled peroxidative reaction with the appropriate chromogen. Alcohol oxidase-peroxidase (AOP) method and corresponding assay kit "Alcotest" was developed in the Institute of Cell Biology, Academy of Sciences of Ukraine (Gonchar et al., 2001; Gonchar \& Sybirny, 1991). Its modification in the form of Multiple Addition Test (MAT) was used for the quantitative determination of ethanol in wines, soft drinks and juices. Analysis of ethanol by three different methods: gas-liquid chromatography, method with alcohol dehydrogenase (kit produced by "Sigma-
Aldrich") and with alcohol oxidase ("Alcotest") showed a high correlation of all three methods ( $\mathrm{R}>0.98$ ) (Kamińska-Kiszka et al., 2011). Analysis of the alcohol content in the tested samples by gas chromatography (GC) showed minor differences in ethanol concentration as compared with the results obtained by enzymatic method (Table 1). To improve the assay sensitivity in analysis of juices and soft drinks, 5-fold increased enzyme concentration in the reaction mixture was used.

Table 1 Ethanol content in selected fruit wines, determined by the use of different analytical methods (Kamińska-Kiszka et al., 2011).

\begin{tabular}{|c|c|c|c|c|c|}
\hline \multirow[t]{2}{*}{ Wine } & \multicolumn{3}{|c|}{ Ethanol content [\%] } & \multicolumn{2}{|c|}{ Difference between methods } \\
\hline & $\begin{array}{c}\text { AOP Routine } \\
\text { Method }\end{array}$ & $\begin{array}{l}\text { Multiple } \\
\text { Addition } \\
\text { Test } \\
\text { (MAT) } \\
\end{array}$ & $\begin{array}{c}\text { Gas } \\
\text { Chromatography } \\
\text { (GC) }\end{array}$ & $\begin{array}{l}\text { AOP-GC } \\
\text { routine }\end{array}$ & MAT-GC \\
\hline Peach Wine „Canelli” & $9.80 \pm 0.50$ & $8.63 \pm 0.43$ & $9.02 \pm 0.11$ & +0.72 & -0.39 \\
\hline $\begin{array}{l}\text { Wild strawberry } \\
\text { wine „Special” }\end{array}$ & $9.22 \pm 0.46$ & $9.94 \pm 0.53$ & $8.2 \pm 0.11$ & +0.70 & +1.42 \\
\hline
\end{tabular}

MAT-variant of the assay allowed detecting trace amounts of alcohol, which is not possible using standard technique. Besides, this variant is five-fold more sensitive (Table 2).

Table 2 Ethanol content (in \%) in juices and non-alcoholic beverages, determined by AOP routine method using 5-fold higher concentration of the enzymes (Kamińska-Kiszka et al., 2011).

\begin{tabular}{|c|c|c|c|c|}
\hline & \multicolumn{4}{|c|}{ Juices and non-alcoholic beverages } \\
\hline & $\begin{array}{c}\text { Strawberry } \\
\text { drink „Cappy” }\end{array}$ & $\begin{array}{l}\text { Apple juice } \\
\text { „Fortuna }\end{array}$ & $\begin{array}{c}\text { Raspberry } \\
\text { passion „Karmi” }\end{array}$ & $\begin{array}{l}\text { Non-alcoholic } \\
\text { beer ,TESCO” }\end{array}$ \\
\hline AOP routine method & $0.035 \pm 0.003$ & $0.024 \pm 0.002$ & $0.009 \pm 0.001$ & $0.005 \pm 0.0005$ \\
\hline $\begin{array}{l}\text { AOP with the use of } \\
5 \text {-fold higher enzyme } \\
\text { concentration }[\%]\end{array}$ & $0.068 \pm 0.004$ & $0.043 \pm 0.003$ & $0.022 \pm 0.002$ & $0.049 \pm 0.003$ \\
\hline
\end{tabular}

The obtained results demonstrate the possibility of using the AOP method for ethanol assay in alcoholic beverages and soft drinks, juices and wines.

AOX can be also used to determine methanol. AOX-catalyzed oxidation of methanol by atmospheric oxygen forms formaldehyde and hydrogen peroxide. In the next peroxidative reaction, hydrogen peroxide oxidizes a chromogen to a colored product, the amount of which can be determined photometrically. Such colored products can be produced during peroxidative oxidation of 2,2'-azinobis (3-ethylobenzotriazoline-6-sulfonic acid) (ABTS) (Verduyn et al., 1984), or a mixture of phenol with 4-aminoantipyrine (Alcool PAP Unitaire, 1992).

Modification of AOP-method for determining an ethanol and methanol using 3,3',5,5' - tetramethylbenzidine (TMB) was developed. This chromogen, in contrast to the others, is non-toxic and non-carcinogenic (Holland et al., 1974).

An enzymatic method for formaldehyde assay based on formaldehyde dehydrogenase was developed and used for testing real samples (Demkiv et al. 2007).

Fish products are an important source of food protein. The fish species Gadidae is only the second (after Clupeidae) in the size of industrial catch, but is much preferred as a food product, whereas Clupeidae is more frequently used in agriculture and industry. The tissues of the Gadidae fish under inappropriate storage, that is, at non-deep freezing conditions $\left(\mathrm{t}>-30{ }^{\circ} \mathrm{C}\right)$, accumulate highly toxic concentrations of FA due to endogenous metabolic reactions, involving namely the natural osmoprotectant trimethylamine-N-oxide, which acts as antifreeze (Reihbein, 1995). Generated FA can cause spoilage of fish, and even make it dangerous for human health if consumed. Fish belonging to the Gadidae family has the highest FA (from $6.4 \pm 1.2 \mathrm{mg} \mathrm{kg}^{-1}$ to $293 \pm 26 \mathrm{mg} \mathrm{kg}^{-1}$ ), exceeding in four cases (among 14) the allowable value of $60 \mathrm{mg} \mathrm{kg}^{-1}$, accepted by the Italian Ministry of Health (Bianchi et al., 2007).

There are described two enzymatic methods for assay of formaldehyde in fish food products using AOX and FdDH isolated from the methylotrophic yeast $H$. polymorpha. AOX-based method exploits an ability of the enzyme to oxidize hydrated form of formaldehyde to formic acid and hydrogen peroxide, monitored in peroxidase-catalyzed colorimetric reaction. In FdDH-based method, a monitored coloured formazane is formed from nitrotetrazolium salt during reduction by $\mathrm{NADH}$, produced in formaldehyde-dependent reaction. The both methods demonstrated that some fish products (hake and cod) contain formaldehyde in high levels (up to $100 \mathrm{mg} \mathrm{kg}^{-1}$ per wet weight) (Sibirny et al., 2011).

Table 3 shows FA content, as measured by different methods. To compare the validity of both enzymatic methods and to evaluate possible interference by the chemical background of the tested samples on analytical results, FA content was analyzed in fish protein-free extracts using a routine method (with an external calibration) as well as a multiple standard addition test (MSAT). Simultaneously, FA content was also analyzed by two chemical methods, using chromotropic acid and MBTH (3-methyl-2-benzothiazolinone hydrazone). As shown in Tab. 3 , there is a good correlation between all analytical data obtained in the MSATvariant of analysis, which was not the case for the results obtained by the routine variant of analysis with external calibration. This may be due to the interference of some components which are co-extracted by TCA (trichloroacetic acid) from the fish tissue. This suggestion is clearly supported by the data obtained by the FdDH-based method (Fig. 1).

Table 3 Results of FA assay (in mg FA per $\mathrm{kg}$ of wet weight of muscle tissue) in protein-free extract of the fish hake, using three independent approaches: FdDH method, MBTH and chromotropic acid (Sibirny et al., 2011).

\begin{tabular}{lcc}
\hline Method & $\begin{array}{c}\text { Multiple standard addition } \\
\text { test }\end{array}$ & Routine test \\
\hline FdDH-based, $\mathrm{M} \pm \mathrm{m}$ & $101.8 \pm 3.2(\mathrm{p}<0.05)^{*}$ & $64.3 \pm 8.6$ \\
$\mathrm{AOX}$-based, $\mathrm{M} \pm \mathrm{m}$ & $95.3 \pm 3.7(\mathrm{p}>0.05)^{* *}$ & $98.0 \pm 3.5$ \\
$\mathrm{MBTH}, \mathrm{M} \pm \mathrm{m}$ & $104.3 \pm 5.6(\mathrm{p}>0.05)^{* *}$ & $106.4 \pm 7.9$ \\
Chromotropic acid, $\mathrm{M} \pm \mathrm{m}$ & $100.5 \pm 1.2(\mathrm{p}>0.05)^{* *}$ & $102.8 \pm 7.3$ \\
\hline
\end{tabular}

*Difference between routine test and MSAT is statistically significant;

**Difference between routine test and MSAT is statistically insignificant.

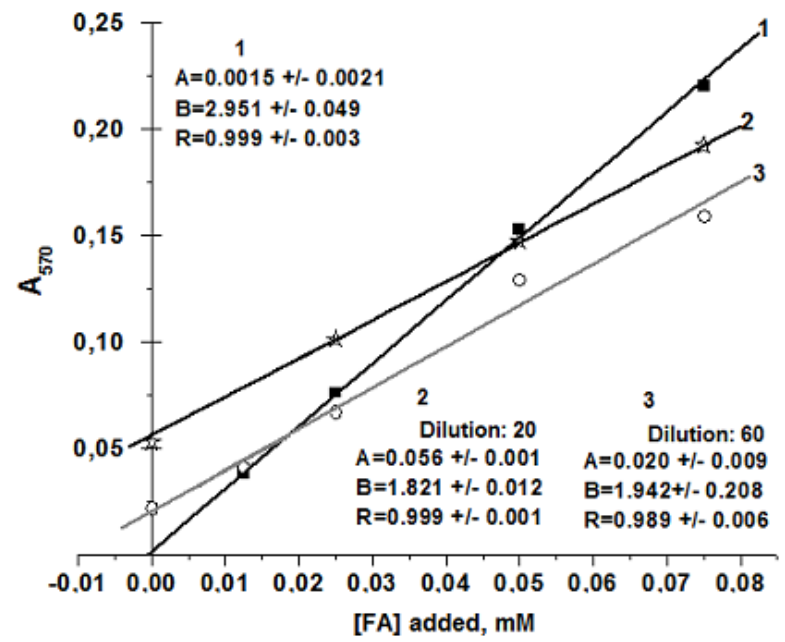

Figure 1 Multiple standard addition test for FA assay in hake, using the FdDHbased method. Curve 1 corresponds to the calibration experiment performed for aqueous solutions of FA (external traditional calibration), and curves 2 and 3 
correspond to the multiple standard addition test (FA was added at different concentrations to the diluted real sample). Some statistical data are presented on the graphs: parameters of linear regression (coefficients of the equation $Y$ $=\mathrm{A}+\mathrm{BX}$, where $\mathrm{Y}$ - optical density, X - FA concentration $(\mathrm{mM}), \mathrm{A}-$ optica density for the sample without addition of exogenous FA, and B - slope value); R - linear regression coefficient (Sibirny et al., 2011).

A flow injection analysis (FIA) system for determination of formaldehyde in frozen fish products was described (Bechmann, 1996). The system provides a rapid and selective determination of formaldehyde in aqueous fish extracts by the combination of a deproteinization procedure and a stopped-flow enzymatic approach in a FL4 system. The FL4 system is furnished with a gel-filtration chromatography column for on-line removal of the proteins from the extract before the enzymatic analysis is performed. Compared with the standard methods for determination of formaldehyde in fish products, the present method is much faster and less affected by interferences. The limit of formaldehyde detection by the proposed method is $2.5 \mathrm{mg} \mathrm{L}^{-1}$. The sampling frequency is about 10 determinations per hour

Combination of alcohol oxidase $(\mathrm{AOX}=\mathrm{MOX})$ and basic fuchsine was confirmed effectively in determining methanol content in model and real systems. The optimal reaction conditions for $20 \mathrm{ppm}$ formaldehyde were determined: $0.1 \%$ basic fuchsine; $35^{\circ} \mathrm{C} ; 2$ hours; $0.25 \mathrm{~N} \mathrm{HCl}$; detection at $560 \mathrm{~nm}$, while those for MOX: 0.8 unit per $1 \mathrm{~mL} ; 25^{\circ} \mathrm{C} ; 30 \mathrm{~min}$. Gas chromatography (GC) confirmed the validity of the developed method with an accuracy of $>95 \%$. Presence of food additives such as sulfite $(100 \mathrm{ppm})$ interfered greatly $(-92 \%)$ with the quantification of methanol, while fruit juice components, galacturonic acid, pectin, glucose, did not apparently interfere the quantification results of methanol. Ethanol (>100 ppm) revealed a competitive inhibition with methanol on MOX. In real samples, fresh fruit juices such as Sunkist, water melon, carrot, carambola, melon, tomato, and papaya were detected to contain $8 ; 31 ; 36 ; 17 ; 8$ 42 , and $38 \mathrm{ppm}$ methanol, respectively, with an accuracy of 93-97\%, as compared to that determined by a GC, suggesting the feasibility of MOX-basic fuchsine method developed for juice industry (Wu et al., 2007).

\section{Biosensor methods}

The degree of selectivity or specificity of the biosensor is determined by the type of the biocomponent. Biological recognizers are divided into 3 groups: biocatalytic, bioaffinity and hybrid receptors (Mello \& Kubota, 2002). The selection of an appropriate immobilization method depends on the nature of the biological element, type of the transducer used, physicochemical properties of the analyte and operating conditions for the biosensor system (Luong et al., 1988). Biosensor can be categorized in several types according to the transducer: potentiometric (Ion-Selective Electrodes (ISEs), Ion-Sensitive Field Effect Transistors (ISFETs), amperometric, impedimetry, calorimetric, optical and piezoelectric transducers. (Turner et al., 1987; Turner, 2013). Among catalytic bioelements of biosensors, the most used are enzymes and microbial cells (Zhao \& Jiang, 2010; Lei et al., 2006; Adeniran et al., 2014).

For determination of formaldehyde, different biosensors have been developed based on microbial cells (Korpan et al., 2000) or enzymes, either AOX (Dzyadevych et al., 2001) or FDH (Herschkovitz et al., 2000; Kataky et al., 2002). The measurement of formaldehyde is based on enzymatic oxidation of formaldehyde by formaldehyde dehydrogenase to formic acid with simultaneous reduction of $\mathrm{NAD}^{+}$to NADH. A number of sensor approaches for the detection of formaldehyde have been published, including systems operating in gas and organic phases (Dennison et al., 1996; Hämmerle et al., 1996; Vianello et al., 1996). For formaldehyde detection with potentiometric biosensors, there were used $\mathrm{pH}$ sensitive field effect transistor (as a transducer) and either the enzyme AOX, or permeabilized yeast cells (containing AOX), as a biorecognition element (Korpan et al., 2000). This biosensor has demonstrated a high selectivity to formaldehyde with no interference response to methanol, ethanol, glucose and glycerol.

The amperometric biosensors (Winter \& Cammann, 1989; Hall et al., 1997) have been suggested for the determination of formaldehyde level. Intact and permeabilized yeast cells were tested as the biorecognition elements for amperometric assay. The mutant C-105 ( $\mathrm{gcrl}$ catX) of the $H$. polymorpha with a high activity of AOX was chosen as the biorecognition element (Gonchar $\boldsymbol{e t}$ al. 2006). Different approaches were used for monitoring FA-dependent cell response including analysis of their oxygen consumption rate by using a Clark electrode and assay of oxidation of redox mediator at a screen-printed platinum electrode covered by cells entrapped in Ca-alginate gel (Khlupova et al., 2007). Bi-enzyme biosensor, using diaphorase from Bacillus stearothermophilus and $\mathrm{NAD}^{+}$- and glutathione (GSH)-dependent FDH from the genetically-engineered yeast $H$. polymorpha as bio-recognition elements, has been developed for determination of formaldehyde. NAD(P)-dependent dehydrogenase-based biosensors have possess several advantages, which make them an obvious candidate for formaldehyde monitoring. Therefore, in order to improve $\mathrm{NAD}(\mathrm{P}) \mathrm{H}$-electrooxidation, 2 types of osmium redox polymers were tested. Both, poly(vinylpyridine)-[osmium- $\left.(N, N \text { '-methylated-2,2'-bimidalzole })_{3}\right]^{3+/ 2+}$ complex (PVI-Os) and poly(1-vinylimidazole), complexed with [Os(4,4' dimethylbipyridine) $\left.{ }_{2} \mathrm{Cl}\right]^{3+/ 2+}$ (PVP-Os), have been successfully used to wire a series of different redox enzymes and were applied for the construction of many biosensors (Nikitina et al., 2007). However, such approach has some disadvantages, because of tedious and time-consuming procedure of biolayer preparation, especially during enzyme immobilization. A new formaldehydeselective biosensor by capacitance versus voltage and impedance measurements using bi-layer bio-recognition membrane has also been developed. As transducers, gold electrodes $\mathrm{SiO}_{2} / \mathrm{Si} / \mathrm{SiO}_{2} / \mathrm{Ti} / \mathrm{Au}$ and Electrolyte-InsulatorSemiconductor $\mathrm{Si} / \mathrm{SiO}_{2}$ (EIS) structures have been used (Ben Ali et al., 2006). As a bio-selective element, recombinant FDH isolated from the gene-engineered strain of the thermotolerant methylotrophic yeast $H$. polymorpha $\mathrm{Tf}$ 11-6 was used as biorecognition element (Sibirny et al., 2011). On the contrary to bacteria FDH, produced from Pseudomonas putida (Tanaka et al., 2003; Fujii et al., 2004), yeast FDH is dependent on 2 low molecular negatively charged compounds - NAD and glutathione (Schütte $\boldsymbol{e t}$ al., 1976). Therefore, to solve the cofactors problem, $\mathrm{NAD}^{+}$and reduced glutathione $(\mathrm{GSH})$ were non-covalently incorporated into a bio-selective sensor membrane in high concentrations (Ben Ali et al., 2006), and an additional negatively charged Nafion membrane, covering the enzyme- and cofactors-containing layer, was used. Such architecture supports the high levels of the cofactors in biomembrane and creates a diffusion barrier, preventing a leakage of the cofactors from the bioactive zone of biosensors. Formaldehyde can be detected within a concentration range from 1 $\mu \mathrm{M}$ to $20 \mathrm{mM}$ (bacteria) and $10 \mu \mathrm{M}$ to $20 \mathrm{mM}$ (yeast). Besides that, the key problems which seriously hamper successful commercialization and a wide usage of the $\mathrm{NAD}^{+}$-based biosensors, developed earlier, are necessity to add exogenous cofactor $\left(\mathrm{NAD}^{+}\right)$into the samples to be analyzed, or to incorporate it covalently into biologically active membrane with supplying the analytical system by $\mathrm{NAD}^{+}$-regeneration system (Ben Ali et al., 2007).

Conductometric enzyme biosensor for determination of formaldehyde in aqueous solutions using interdigitated thin-film planar electrodes and immobilized AOX from $H$. polymorpha has been developed. The operational stability was less than 20 h (Dzyadevych et al., 2001). Biosensor, based on immobilized formaldehyde dehydrogenase (FDH), and exploited at continuous flow conditions, has a better stability (at least 3 months) (Vianello et al., 2007).

The newly developed formaldehyde biosensor, based on FDH and $\mathrm{NAD}^{+}$, was used for the detection of formaldehyde in fish samples. To maximize the reaction rate, the enzyme acts as biorecognition immobilized with Nafion membrane which is chemically modified on gold electrode (Marzuki et al., 2012). In the system, 0.1 M potassium phosphate was used as the supporting electrolyte and $0.5 \mathrm{mM} \mathrm{NAD}^{+}$was added as the coenzyme. The optimum scan rate was found at $0.1 \mathrm{~V} / \mathrm{s}$ while the optimum $\mathrm{pH}$ was at 8 via cyclic voltammetry. A linear response was ranged from 1 to $10 \mathrm{ppm}$ of formaldehyde, with correlation coefficient $\left(\mathrm{R}^{2}\right)$ equals to 0.9865 ( $\mathrm{RSD}<3.05 \%$ ). The response time was found less than $1 \mathrm{~min}$. Formaldehyde biosensor showed reproducibility with no significant different $(\mathrm{p}>$ $0.05)$ at 1,5 and $10 \mathrm{ppm}$ of formaldehyde $(\mathrm{n}=10)$. For interferences study, it was showed that the biosensor response retained its specificity for formaldehyde and did not respond to equivalent additions of methanol and also ethanol and gave the percentage of formaldehyde recovered ranging from $99.0 \%$ to $99.8 \%$.

A portable bienzymatic analytical system was developed for the chronoamperometric analysis of methanol-ethanol mixtures. The system consists of two biosensors, one based on alcohol dehydrogenase (ADH) that responds only to the ethanol and the second one based on AOX that responds to both methanol and ethanol. The transducers were screen-printed electrodes (SPEs) modified with mediators: Meldola blue for ADH and Co-phthalocyanine for AOX (Bucur et al., 2008). The use of nanomaterials in biosensors has allowed the introduction of many new signal transduction technologies into biosensorics and the improvement of bioanalytical parameters of the nanosensors: selectivity, response time, miniaturization of the biorecognition unit (Murphy, 2006).

A simple visual ethanol biosensor based on AOX immobilized onto polyaniline (PANI) film for halal verification of fermented beverage samples is described. This biosensor responds to ethanol via a colour change from green to blue, due to the enzymatic reaction of ethanol that produces acetaldehyde and hydrogen peroxide, when the latter oxidizes the PANI film. The procedure to obtain this biosensor consists of the immobilization of AOX onto PANI film by adsorption. For this, an AOX solution is deposited on the PANI film and left at room temperature until dried (30 $\mathrm{min}$ ). The biosensor was constructed as a dip stick for visual and simple use. The colour changes of the films have been scanned and analyzed using image analysis software (i.e., ImageJ) to study the characteristics of the biosensor's response toward ethanol. The biosensor has a linear response in an ethanol concentration range of $0.01 \%-0.8 \%$, with a correlation coefficient $(\mathrm{R})$ of 0.996 . The limit detection of the biosensor was $0.001 \%$, with reproducibility (RSD) of $1.6 \%$ and a life time up to seven weeks when stored at $4{ }^{\circ} \mathrm{C}$. The biosensor provides accurate results for ethanol determination in fermented drinks and was in good agreement with the standard method (gas chromatography) results. Thus, the biosensor could be used as a simple visual method for ethanol determination in fermented beverage samples that can be useful for Muslim community for halal verification (Kuswandi et al., 2014).

Thus, biosensors are promising tools and have a potential application for the determination of formaldehyde, methanol and ethanol in different food products, 
because they are simple, fast, reusable, reproducible, sensitive, valid, have good storage stability, and are not sensitive to many interferences.

\section{CONCLUSION}

Summarizing, we can conclude on the effectiveness of enzymatic and biosensor approaches for ethanol, methanol and formaldehyde assay in food products Especially promising are the biosensor approaches, using AOX and FDH of the methylotrophic yeasts.

Acknowledgments: The work was supported by the Cross-border Cooperation Programme Poland-Belarus-Ukraine 2007-2013 in the frame of the project IPBU.03.01.00-18-452/11-00 "Scientific integration of the Polish-Ukrainian borderland area in the field of monitoring and detoxification of harmful substances in environment" and by the Polish Ministry of Science and Higher Education funds for science in 2013-2015 for an international co-financed project (decision number 3020/PBU/0755/11/13/2014/2 "Scientific integration of the Polish-Ukrainian borderland area in the field of monitoring and detoxification of harmful substances in environment"). Responsibility for the content of this publication lies solely with the authors and can not under any circumstances be considered to reflect the position of the European Union in any way.

\section{REFERENCES}

ADENIRAN, A., SHERER, M., TYO, K.E.J. Yeast-based biosensors: design and applications. 2014. FEMS Yeast Res. http://dx.doi.org/ 10.1111/1567. 1364.12203

ALCOHOL DEHYDROGENASE ASSAY. http://www.worthingtonbiochem.com/ADH/assay.html

ALCOOL PAP UNITAIRE. 1992. Enzymatic determination of ethanol in serum or whole blood. Instruction for kit produced by "BioMerieux" (Lyon, France), 12.

AXELROD, J., DALY, J. 1965. Pituitary gland: enzymic formation of methanol from S-adenosylmethionine. Science, 158, 892-993. http://dx.doi.org/10.1126/science.150.3698.892

BECHMANN, I.E. 1996. Determination of formaldehyde in frozen fish with formaldehyde dehydrogenase using a flow injection system with an incorporated gel-filtration chromatography column. Anal. Chim. Acta, 320, 155-164 http://dx.doi.org/1016/0003-2670(95)00561-7

BEN ALI, M., KORPAN, Y., GONCHAR, M., EL'SKAYA, A, MAAREF, M.A., JAFFREZIC-RENAULT, N., MARTELET, C. 2006. Formaldehyde assay by capacitance versus voltage and impedance measurements using be-layer biorecognition membrane. Biosens. Bioelectron. 22, 575-581. http://dx.doi.org/10.1016/j.bios.2006.01.019

BEN ALI, M., GONCHAR, M., GAYDA, G., PARYZHAK, S., MAAREF, M.A., JAFFREZIC-RENAULT, N., KORPAN, Y. 2007. Formaldehyde-sensitive sensor based on recombinant formaldehyde dehydrogenase using capacitance versus voltage measurements. Biosens. Bioelectron.. 22, 2790-2795. http://dx.doi.org/10.1016/j.bios.2006.10.002

BIANCHI, F.,CARERI, M. MUSCI, M., MANGIA, A. 2007. Fish and food safety: Determination of formaldehyde in 12 fish species by SPME extraction and GC-MS analysis. Food Chemistry, 100, 1049-1053. http://dx.doi.org/10.1016/j.foodchem.2005.09.089

BUCUR, B, RADU, G, TOADER, C. 2008. Analysis of methanol-ethanol mixtures from falsified beverages using a dual biosensors amperometric system based on alcohol dehydrogenase and alcohol oxidase. European Food Research and Technology, 226(6):1335.

CASANOVA, M., DEYO, D.F., HECK, H.D'A. 1989. Covalent Binding of Inhaled Formaldehyde to DNA in the Nasal Mucosa of Fischer 344 Rats: Analysis of Formaldehyde and DNA by High-Performance Liquid Chromatography and Provisional Pharmacokinetic Interpretation. Toxicological Sciences, 12, 397-417. http://dx.doi.org/10.1093/toxsci/12.3.397

DEMKIV, O.M., PARYZHAK, S.Y., GAYDA, G.Z., SIBIRNY, V.A., GONCHAR, M.V. 2007. Formaldehyde dehydrogenase from recombinant yeas Hansenula polymorpha: isolation and bioanalitical application. FEMS Yeast Res. 7, 1153-1159. http://dx.doi.org/10.1111/j.1567-1364.2007.00255.x

DENNISON, M.J., HALL, J.M., TURNER, A.P.F. 1996. Direct monitoring of formaldehyde vapour and detection of ethanol vapour using dehydrogenase-based biosensors. Analyst, 121, 1769-1774. http://dx.doi.org/10.1039/AN9962101769 DZYADEVYCH, S.V., ARKHYPOVA, V.N., KORPAN, Y.I. 2001 Conductometric formaldehyde sensitive biosensor with specifically adapted analytical characteristics. Anal. Chim. Acta, 445, 47-55. http://dx.doi.org/10.1016/S0003-2670(01)01249-1

FUJII, Y., YAMASAKI, Y., MATSEMOTO, M. 2004. The artificial evolution of an enzyme by random mutagenesis: The development of formaldehyde dehydrogenase. Biosci. Biotechnol. Biochem., 68, 1722-1727. http://dx.doi.org/10.1271/bbb.68.1722

GERBERICH, H., SEAMAN, G. 1994. Formaldehyde. In: Encyclopedia of Chemical Technology. $4^{\text {th }}$ edit. V. 11, John Wiley \& Sons (Ed.), p. 929-951, New York, ISBN: 0-471-41961-3.
GONCHAR, M.V., SYBIRNY A.A. 1991. Sposob opredelenija perekisi vodoroda $\mathrm{v}$ biologicheskich obiektach. Avtorskoe svidetelstvo (patent) SSSR 1636772. Bull. Izobretenij N11.

GONCHAR M.V., MAIDAN, M.M., PAVLISHKO, H.M., SIBIRNY, A.A. 2001. A new oxidase-peroxidase kit for ethanol assays in alcoholic beverages. Food Technol. Biotechnol., 39, 37-42.

GONCHAR, M.V., RYABOVA, O.B., DMYTRUK, K.V., ZAKALSKA, O.M. SMUTOK, O.V., PAVLISHKO, H.M., GAYDA, G.Z., SIBIRNY, V.A., SYBIRNY, A.A. 2006. Isolation and characterization of the mutant forms of Hansenula polymorpha alcohol oxidase as a selective element of the amperometric biosensor. In: Investigations on sensor systems and Technologies Ed. By A.V. Elskaya and V.D. Pokhodenko. Kiev, National Acad. Sci. of Ukraine, p. 134-140.

HALL, E.A.H., PREUSS, J.J., GOODING J.J., HÄMMERLE, M. 1997 Exploring Sensors to Monitor Some Environmental Discharges: Laboratory Innovation versus Design and Manufacturability, in Biosensor for Direct Monitoring of Environmental Pollutants in Field, Ed. D.P. Nikolelis, U. L. Krull,

J. Wang, M. Mascini, NATO ASI Series, Series 2: Environment - Vol. 38 , Kluwer, London, pp 227-237.

HÄMMERLE, M., HALL, E.A.H., CADE, N. 1996. Electrochemical enzyme sensor for formaldehyde operating in the gas phase. Biosens. Bioelectron., 11, 239-246. http://dx.doi.org/10.1016/0956-5663(96)88410-7

HERSCHKOVITZ, Y., ESHKENAZI, I., CAMPBELL, C.E. 2000. An electrochemical biosensor for formaldehyde. J. Electroanal. Chem., 491, 182 187. http://dx.doi.org/10.1016/S0022-0728(00)00170-4

HOLLAND, V.R., SAUNDERS, B.C., ROSE, F.L., WALPOLE, A.L. 1974. A safer substitute for benzidine in the detection of blood. Tetrahedron , 30, 3299 3302. http://doi.org/10.1016/S0040-4020(01)97504-0

KAMIŃSKA-KISZKA, E., WIT, Ł., SIBIRNA, L., SIBIRNY, V., GONCHAR, M. 2011. Oznaczanie zawartości etanolu metoda enzymatyczna w winach napojach owocowych oraz sokach. Żywność. Nauka. Technologia. Jakość, 4, 45 57.

KATAKY, R., BRYCE, M.R., GOLDENBERG, L. 2002. A biosensor for monitoring formaldehyde using new lipophilic tetrathiaful valenetetracyanoquinodimethane salt and a polyurethane membrane. Talanta, 56, 451458. http://dx.doi.org/10.1016/S0039-9140(01)00567-7

KHLUPOVA, M., KUZNETSOV, B., DEMKIV, O. 2007. Intact and permeabilized cells of the yeast Hansenula polymorpha as bioselective elements for amperometric assay of formaldehyde. Talanta, 71, 934-940. http://dx.doi.org/10.1016/j.talanta.2006.05.069

KORPAN, Y.I., GONCHAR, M.V., SIBIRNY, A.A. 2000. Development of highly selective and stable potentiometric sensors for formaldehyde $\begin{array}{llll}\text { determination. } & \text { Biosens. } & \text { Bioelectron., } & \text { 15, }\end{array}$ http://dx.doi.org/10.1016/S0956-5663(00)00054-3

KROTOSZYNSKI, B.K., BRUNEAU, G.M., O'NEILL, H.J. 1979. Measuremen of chemical inhalation exposure in urban populations in the presence of endogenous effluents. J. Anal. Toxicol., 3, 225-234.

KUSWANDI, B., IRMAWATI, T, MOCH AMRUN HIDAYAT, M.A., AHMAD, J.M. 2014. A simple visual ethanol biosensor based on alcohol oxidase immobilized onto polyaniline film for halal verification of fermented beverage samples. Sensors, 14(2), 2135-2149. http://dx.doi.org/10.3390/s140202135 LEI, YU., CHEN, W., MULCHANDANI, A. 2006. Microbial biosensors. Anal. Chim. Acta, 568, 200-210. http://dx.doi.org /10.1016/i.aca.2005.11.065 LUONG, J.H.T., MULCHANDANI, A., GUILBAUL, G.G. 1988. Developments and applications of biosensors. Trends Biotechnol., 6, 310-316. http://dx.doi.org/10.1016/0167-7799(88)90026-1

MAGNUSSON, A. 2013. Formox and formaldehyde market update - A turbo in the future? http://www.methanolmsa.com/wpcontent/uploads/2013/11/Andreas-Magnusson.pdf

MARZUKI, N.I., ABU BAKAR, F., SALLEH, A.B., LEE YOOK HENG, L.Y., SIDDIQUEE, N.A. 2012. Development of Electrochemical Biosensor for Formaldehyde Determination Based on Immobilized Enzyme. Int. J. Electrochem. Sci., 7, 6070-6083.

MEDINSKY, M.A., DORMAN, D.C., BOND, J.A., MOSS, O.R., JANSZEN D.B., EVERITT, J.I. 1997. Pharmacocinetics of methanol and formate in female cynomolgus exposed to methanol vapors. Res. Rep. Health Eff. Inst. 77, 31-38.

MELLO, L.D., KUBOTA, L.T. 2002. Review of the use of biosensors as analytical tools in the food and drink industries. Food Chem., 77, 237-256. http://dx.doi.org/10.1016/S0308-8146(02)00104-8

WU, M.C., JIANG, C.M., HO, Y.T., SHEN, S.C., HUNG-MIN CHANG, N.M 2007. Convenient quantification of methanol in juices by methanol oxidase in combination with basic fuchsin. Food Chemistry, 100, 412-418 http://dx.doi.org/10.1016/j.foodchem.2005.09.017

MURPHY, L. 2006. Biosensors and bioelectrochemistry. Current Opinion in Chemical Biology, 10, 177-184. http://dx.doi.org/10.1016/j.cbpa.2006.02.023

NIKITINA, O., SHLEEV, S., GAYDA, G., DEMKIV, O., GONCHAR, M. GORTON, L., CSÖREGI, E., NISTOR, M. 2007. Bi-enzyme biosensor based on NAD+- and glutathione-dependent recombinant formaldehyde dehydrogenase and diaphorase for formaldehyde assay. Sens. Actuat. B Chem. 125. 1-9. http://dx.doi.org/10.1016/j.snb.2007.01.025 
PAVLISHKO, H.M., HONCHAR, T.M., GONCHAR, M.V. 2003. Chemical and enzymatic assay of formaldehyde content in fish food. Experiment Clin Physiol Biochem. 4, 56-63. (In Ukrainian).

REHBEIN, H., EICHENAUER, D., FESER, P., FRIEDRICH, R., GLÜCK, B., HARZ, A., WARNING, W., WERKMEISTER, K., WINKLER, F. 1995. Formaldehyd und Dimethylamin in tiefgekuhlten Fischerzeugnissen aus dem Handeleine Bestandsaufnahme. Archiv Lebensmittelhyg., 46, 122-124.

RESHETILOV, A., ILIASOV, P., RESHETILOVA, T., MAHENDRA RAI 2011. Nanosensors and their applications. In Metal nanoparticles in microbiology. Ed: Mahendra Rai, Nelson Duran. Springer Heidelberg, Dordrecht, London, NewYork. p. 269-283. ISBN 978-3-642-18311-9. http://dx.doi.org/ 10.1007/978-3-642-18312-6

SCHECHTER, D.S., SINGER, P.C. 1995. Formation of aldehydes during ozonation. Ozone Sci Sng. 17, 53-55. http://dx.doi.org/10.1080/01919519508547577

SCHÜTTE, H., FLOSSDORF, J., SAHM, H., KULA, M.R. 1976. Purification and properties of formaldehyde dehydrogenase and formate dehydrogenase from Candida boidinii. Eur. J. Biochem., 62, 151-160. http://dx.doi.org/10.1111/j.1432-1033.1976.tb10108.x

SIBIRNY, V., DEMKIV, O., KLEPACH, H., HONCHAR, T., GONCHAR, M 2011. Alcohol oxidase- and formaldehyde dehydrogenase-based enzymatic methods for formaldehyde assay in fish foods products. Food Chemistry, 127, 774-779. http://dx.doi.org/10.1016/j.foodchem.2010.12.146

SMUTOK, O., GAYDA, G., DMYTRUK, K., KLEPACH, H., NISNEVITCH, M., SIBIRNY, A., PUCHALSKI, CZ., BRODA, D., SCHUHMANN, W., GONCHA,R M., SIBIRNY, V. 2011. Amperometric biosensors for lactate, alcohols and glycerol assays in clinical diagnostics. In: Biosensors for Health, Environment and Biosecurity, Book 1, InTech Open Access Publisher, p. 401446. ISBN 979-953-307-001-7. http://dx.doi.org/10.5772/16643

SIBIRNY, V., DEMKIV, O., PARYZHAK, S., KLEPACH, H., KORPAN, Y., SMUTOK, O., NISNEVICH, M., GAYDA, G., PUCHALSKI, CZ., GONCHAR, M. 2011. Formaldehyde-oxidizing enzymes and genetically modified yeast Hansenula polymorpha cells in monitoring and removal of formaldehyde. In: Waste Water - Evaluation and Management, InTech Open Access Publisher, p. 115-154. ISBN: 978-953-307-233-3. http://dx.doi.org/10.5772/16148

STEGINK, L.D., BRUMMEL, M.C., MCMARTIN, K.E., MARTIN-AMAT, G. FILER, L.J. JR, BAKER, G.L., TEPHLY, T.R. 1981. Blood methanol concentrations in normal adult subjects administered abuse doses of aspartame. $J$. Toxicol. Environ. Health, 281-290. http://dx.doi.org/10.1080/15287398109529979

TANAKA, N., KUSAKABE, T., ITO, K. 2003. Crystal structure of glutathioneindependent formaldehyde dehydrogenase. Chemico-Biol. Interact., 143-144, 211-218. http://dx.doi.org/10.1016/S0009-2797(02)00168-0

TROTSENKO, Y.A., TORGONSKAYA, M.L. Metilotrofnye drozzi. Moskva, TR-Print, 2011, 313 P. ISBN 978-5-905039-11-9. (in Russian)

TURNER, A., WILSON, G., KAUBE, I. (eds.).1987. Biosensors: Fundamentals and Applications. Oxford, UK: Oxford University Press. 770 p. ISBN 0198547242

TURNER, A.P.F. 2013. Biosensors: sense and sensibility. Soc. Rev., 42, 3184 3196.

http://dx.doi.org/10.1039/C3CS35528D

WANG, M-L., WANG, J-T., CHOONG, M-Y. 2004. A rapid and accurate method for determination of methanol in alcoholic beverages by direct injection capillary gas chromatography. Journal of Food Composition and Analysis., 17, 187-196. http://dx.doi.org/10.1016/i.j.jca.2003.08.006

VERDUYN, C., VAN DIJKEN, J., SCHEFFERS, W. 1984. Colorimetric alcohol assays with alcohol oxidase. J. Microbiol. Methods. 2, 15-25. http://dx.doi.org/10.1016/0167-7012(84)90027-7

VIANELLO, F., STEFANI, A., DI PAOLO, M.L. 1996. Potentiometric detection of formaldehyde in air by an aldehyde dehydrogenase FET. Sens. Actuat. B Chem., 37, 49-54. http://dx.doi.org/10.1016/S0925-4005(97)80071-8

VIANELLO, F., BOSCOLO-CHIO, R., SIGNORINI, S., RIGO, A. 2007. Online detection of atmospheric formaldehyde by a conductometric biosensor. Biosens Bioelectron. 22(6):920-5.

WINTER, B., CAMMANN, K. 1989. Formaldehyde analysis by electrochemical biosensor-FIA. Fresenius Zeitschrift FurAnalytische Chemie, 334, 720-721. WWW.GLOBALRFA.COM (http://globalrfa.org/news-media/global-ethanolproduction-will-rise-to-over-90-billion-litres-in-2014)

ZANON, J.P., PERES, M.F.S., GATTÁS E.A.L. 2007. Colorimetric assay of ethanol using alcohol dehydrogenase from dry baker's yeast. Enzyme and Microbial Technology, 40, 466-470. http://dx.doi.org/10.1016/j.enzmictec.2006.07.029

ZHAO, Z., JIANG, H. 2010. Enzyme-based Electrochemical Biosensors. In: Biosensors, InTech Open Access Publisher, 302 p. ISBN 978-953-7619-99-2. http://dx.doi.org/10.5772/7200 